\title{
Homatropine Methylbromide
}

National Cancer Institute

\section{Source}

National Cancer Institute. Homatropine Methylbromide. NCI Thesaurus. Code C61784.

The methylbromide salt of homatropine, a synthetic tertiary amine alkaloid with antimuscarinic properties. Homatropine methylbromide, a competitive inhibitor of acetylcholine at the muscarinic receptor, blocks parasympathetic nerve stimulation, thereby inhibiting pepsin and gastrin secretion. When administered in high doses, this drug produces inhibitory effects on acetylcholine activity, specifically on smooth muscle located in the gastrointestinal, biliary, and genitourinary tracts, resulting in an antispasmodic effect. 